\title{
Researching Social Change in Bali Indigenous Marriage Private
}

\author{
I Nyoman Budiana* and Made Oka Cahyadi Wiguna \\ Universitas Pendidikan Nasional \\ *budiananyoman1961@gmail.com
}

Published: 31/08/2021

How to cite:

Budiana, I, N., Wiguna, M, O, C. Researching Social Change in Bali Indigenous Marriage Private. Sociological Jurisprudence Journal. Volume 4 Issue 2. Page 75 - 85. https://doi.org/10.22225/scj.4.2.2021.75-85

\begin{abstract}
This article wants to understand and analyze the phenomenon of Balinese customary life arrangements related to changes in marital procedures. To be able to produce accurate findings, social phenomena are examined in detail and in-depth through qualitative research, with a phenomenological paradigm. With this paradigm the results are obtained in the form of empirical data and in-depth understanding relating to variations in categories, properties, and attributes related to the changing phenomena of cultural traditions and adat ngerorod marriage. In detail the findings generated that in social reality, the indigenous Balinese have constructed changes in the pattern of marriage from the way of ngerorod or selarian (running together) to switch to the memadik or propose, because the pattern of memadik or ask is seen to better reflect equality and justice in society. The rationale that drives is the existence of a reaction to discriminatory customary norms; innovative faith-based constructive thinking; increasing the level of education and parental-bilateral kinship thinking. Memadik marriage by means of marriage or marriage, implies a marriage as a result of the construction of modern society.
\end{abstract}

Keywords: cultural traditions; ngerorod marriages and memadik marriages; social change

\section{INTRODUCTION}

The tradition of traditional life and cultural traditions in the midst of Balinese life is so rich, unique and of high value. Such conditions of customary life are as if they are not obsolete and timeless by the progress of the times such as now, even have been wracked by the harsh currents of globalization that are more oriented toward materialist-individualistic, but empirically cultural traditions, customs that lead to increased dignity and dignity humans apparently still exist and remain to be maintained and developed because it is more in line with egalitarian human civilization.

Bali as one of the small islands among thousands of islands in the archipelago, has various types of cultural traditions, customs and customs adiluhung which is carried out in the order of everyday life. Various types of cultural traditions and customs that live and develop well, including cultural traditions, marriage customs. Cultural traditions and customs of marriage carried out in the life of Balinese people are closely related to the kinship system adopted by the community itself, (Poespasari, 2018: 12). Bali applies a patrilineal kinship system or more precisely applies the purusa kinship system, in which the responsibility of continuing the family lineage is drawn from the male or purusa line, so that the customary marriage is carried out by attracting women to enter the family family of men and then continue the descent in the family family of men, (Korn, 1978: 1; Windia, et.al, 2008: 14-15).

When viewed from the way of marriage, Balinese people have long since applied cultural traditions, adat ngerorod marriages or selarian marriages or also called running together, (Utomo, 2017: 96). In addition, marriage is also applied by means of memadik or marriage law in accordance with the term marriage by proposing marriage, especially in the community in groups or household equivalent or equivalent, (Korn in Panetja, (2004: 66). Marriage by way of ngerorod is done by a male partner with a woman who first promises to a certain place to meet and subsequently agrees to marry together to go to 
the house of a male relative.In marriages by means of ngerorod, parents of women tend to not know that her daughter has agreed to marry a man as her future husband, (Panetja, 2004: 63). The parents or family of the woman only find out that her daughter has married, when the male family comes to the house of the woman called adatngeluku or mapejatian, while marriage by means of mepadik or propose, from the beginning of the second parent $\mathrm{b} n$ parties already know that their children will get married. The whole series of marriages from the process of introducing parents, marriage talks, and marriage ceremonies and up to the ceremony stage majejauman to the bride's house carried out by agreement of the two parties of the family.

Of the two ways adopted by the Balinese in conducting marriages, the cultural traditions and customary marriages most commonly performed are marriages by means of ngerorod, both within the community environment in the strata of the Shudras of Wangsa and between Shudras of Wangsa with the strata of threeof Wangsa. Windia, (2014: 288), states that this ngerorod marriage pattern, when viewed from the provisions of the marriage law is also declared legally valid, which is in accordance with the sound of Article 2 paragraph (1) of Law Number 1 of 1974 concerning Marriage which states "marriage is legal if it is done according to the laws of each religion and belief".

However, along with the development of the era moreover after the reform era, the cultural traditions and customs of marriage in ngerorod manner have experienced very rapid changes, where the Balinese people tend to have marriages by means of memadik or propose. How to make a memadik respect more dignity and human dignity as God's creation and more in accordance with the purpose of marriage itself.

Several previous relevant studies have concluded that, mixed marriages in Jembrana Bali are related to mediation and fragmentation of citizenship and identity (Bagus, 2008); Cross-caste marriage in Bali a gender analysis of caste and its impact on Balinese women (Cahyaningtyas, 2016); Ngerorod's marriage waned in Balinese society and shifted to woo culture (Lusiani, 2015); problematic and alternative solutions to various national marriages (Aditi, 2019); a marital system and legal consequences for children born in it (Diatmika and Sujana, 2019); marriage problems in Bali (Boon, 1976); the punishment of a Brahmin women's marriage in Bali (Sadnyini, 2016); the most common cultural traditions and customs of marriage are ngerorod marriages (Windia, 2014); Intracultural Rules and Results in the Three Domestic Cultures (Collier, Ribeau, \& Hecht, 1986); Consensus Dialectics and Conflict in Intracultural Communication (Toyosaki, 2011); Cultural centrality (Shuter, 1990); Strategies for cultural preservation in Hindu Bali (Widana, 2017); Balinese local wisdom (Suastra, 2017); Strength, support and supporting factors for early marriage (Karjono, 2017). Self Identification and Repositioning of Middle Easterners in the Discourse of Indigenous Communities in Bali (Suyadnya, 2019).

The novelty of this research lies in the pattern of changing cultural traditions and customs of ngerorod marriages that occur in Balinese society; the rationale for the change from the way of the ngerorod shifts to the way of memadik or propose, and the meaning contained in the changing cultural traditions and customs of ngerorod marriages in Balinese society.

Some research questions are: 1) how are the changing patterns of ngerorod cultural traditions and customs of marriage occurring in Balinese society today; 2) what is the rationale for the Balinese indigenous people to make changes in carrying out marriages, from the way of the ngerorod switch to the method of memadik or proposing marriage; 3) what values and meanings are contained in the changing cultural traditions and customs of ngerorod marriages in Balinese society?

In the context of social theory, Berger and Luckman (1966: 68) argue that such behavior is a sign of social construction in society, namely the existence of individual desires in the community to carry out new constructions that are different from previous behavior. In seeing the relationship between human beings and society in social construction is carried out through a dialectical process consisting of three stages, namely externalization, objectivation and internalization.

Van Gennep (Wignjodipoero, 1985: 122-123), whichever method is taken in the implementation of marriage is essentially a series of magical acts aimed at harmonizing the micro and macro-cosmos world so that the bride and groom both gain peace, happiness and fertility. Furthermore, the series of actions is called rites de passage or a series of transitional ceremonies. This ceremony is also meant as a symbol of the transition (change) of the status of the bride and groom who previously lived separately, then after going through the process of this ceremony the bride and groom become united in life together as 
husband and wife. This transitional ceremony consists of three elements, namely: a) rites de sparation (initial status separation ceremony); b) rites de marge (ceremonies traveling to new status); and c) rites de aggregation (new status acceptance ceremony).

According to Comte and Spencer, (Poloma, 1987: 25), society is seen as a social system consisting of interdependent parts of one another. Therefore customary institutions as one of the existing structures in the community are expected to provide a sense of security and comfort so as to create a harmonious community life. Pitana (1999: 16) states that traditional villages must be able to become a vehicle for developing various positive values that exist in Balinese culture such as democratic values, tolerance, adaptation, creativity, flexibility and others, as well as a vehicle for eliminating various traditions that are not in accordance with a changing social and economic environment. Customary villages must be able to sort and choose traditions that must be developed and traditions that must be abandoned.

Customs as a product of customary law which is very discriminatory and passed on to the previous generation of young people are the result of decisions based on the king's past plays and are hegemonic. Such a case, if examined from Dahrendorf's view is a reflection of the existence of power and authority that always places individuals in the upper and lower positions and any individual who is not subject to the existing authority will be subject to sanctions. The community in such a situation is said by Dahrendorf to be an imperatively coordinated association. Conflicts occur because of differences in authority and position, both of which are social realities. Differences in authority and position among individuals in society will cause class conflicts. Opposition occurs where the ruling class maintains the status quo, while the ruling class seeks to make changes (Dahrendorf, 1986: 255-257).

The concept of power by Hobbes says that differences in interpretation based on ratios and unequal desires cause power struggles because desires give purpose to human action, while ratios intimidate the means to achieve that goal in the most tangible form called power (Cambell, 1994: 90-91 ).

Acceptance of innovation by individuals in society will be influenced by socio-cultural and social systems. There are three important aspects in the social system namely norms, role models and agents of change. Norms affect individual reactions to innovation and norms that have more modern nature will more quickly accept innovation. Besides, norms, role models are important aspects of social systems related to innovation. Role models are able to influence others because of their skills, their compatibility with the norm and because of their status, even though at first they were not required to accept innovation. While the third aspect of the social system is an agent of change, which is a professional trying to mend

The concept of thought stated above, seen from the perspective of theory in the paradigm of social definition, explains that humans are creative actors of their social reality. Human action is not entirely determined by the norms, habits and values that describe social structures and institutions in society. Humans in many ways have the freedom to act outside the limits of the control structures and social institutions in which individual human beings originate. Humans actively and creatively develop themselves through responses to stimuli in their cognitive world. In social processes, individual human beings are seen as creators of reality that are relatively free in their social world (Ritzer, 1992: 50).

Lusiani, (2015) the perspective of the Balinese people in the village of Tri Mulyo Mataram on ngerorod marriage has changed. Ngerorod marriage which was initially considered the best way of marriage is slowly being abandoned because of the way of marriage, which is marriage / proposition which is considered better and can be accepted by the wider community. Education is the cause of the fading tradition of ngerorod marriage in the Balinese community in Kampung Tri Mulyo Mataram, Seputih Mataram District, Central Lampung Regency.

Aditi (2019) concluded that due to changes in the determination of the social stratification system, women were psychologically depressed because of injustice. The alternative is that if a marriage between a Three of Wangsa woman and a man outside the Three of Wangsa is the marriage process of the ngerorod or elopement models.

Limarandani, Sihabudin\& Ronda (2019) explained that, customary law is not only part of symbolism but can be converted as part of their cultural identity which is carried out in the lives of every Balinese citizen as well as being a binder of people's behavior. Nyerod is still a disgrace to families of women who marry with men who have a lower caste than women. 
Sadnyini (2016) A marriage of a Brahmin woman with a different caste man in Bali is a mixed marriage. Marriage sanctions are still carried out in particular sanctions patiwangi ceremony and other social sanctions. Sanctions are killed by plunging into the fire, thrown into the sea, sequestered, sanctions downgraded, and not allowed to go home. The sanction of marriage from a Hindu perspective is contrary to the teachings of Tri Hita Karana, Tri Kaya Parisudha, VasudaivaKutumbakam, Tat.

\section{METHOD}

The writing method used to examine social change in the way of marriage to the structure of Balinese society is to use a qualitative approach with a phenomenological paradigm, (Satori, et al (2017: 34). The qualitative approach chosen in writing this article is intended to produce descriptive data in the form of views, thoughts through written or verbal information from each individual and observable behavior from the subject under study, in addition, this qualitative approach is directed at the background and phenomena studied, namely the bridal couple who have made changes in marriage by asking for marriage or memadik independently, holistically and intactly To obtain valid data, information is collected through in-depth interviews conducted with traditional leaders in the Balinese traditional community structure, such as a number of Customary Villages / Customary Heads, Religious Leaders and other figures who understand the social phenomena being studied.

The application of this method is intended to produce a number of detailed data and information according to the essential meaning of the actors (actors) and the subject under study. So the meaning of a number of data and information collected from the field is related to aspects of changes in the context of marriage and pre-characteristic and categorical changes to traditional leaders, religious leaders, individuals as a bridal couple who have engaged in memadik or propose, so that answers will be obtained as well in-depth understanding of the problem.

\section{III.RESULTS AND DISCUSSION}

\section{Patterns of Traditional Change in Marriage of Balinese Communities}

The phenomenon of marriage in the structure of Balinese life can be done through two forms, namely the form of ordinary marriage and the form of marriage nyeburin. From the perspective of the kinship system, the Balinese people adhere to a patrilineal kinship system or in Balinese terms known as the kapurusa. Therefore marriages that are carried out in the form of ordinary marriages are carried out by inviting the bride into the family family of men and then the offspring born are drawn from the male lineage (purusa).

Whereas if the marriage is carried out by the bride and groom carried out in the form of a nyeburin marriage, then the custom that occurs in Balinese society, the bridegroom is invited to enter the family family of the bride and continue the descendants within the bride's family. In the context of nyeburin marriage, according to Balinese customary law the bride is confirmed to be a male status or in Balinese customary law known as the rajeg senata, while the bridegroom's status changes to predana (Windia, 2014: 321).

The process of inauguration of the bride and groom becomes the status of a man (sentana rajeg) is generally carried out during the wedding ceremony of the bride and groom couples witnessed by the traditional village or traditional village administrators and local village administrative apparatus. The marriage ceremony for the Balinese is known as the mabyekala and widhiwedana ceremonies. So in nyeburin marriage, this ceremony also symbolizes the transition of the bride's status as a man or sentana rajeg and his legal symbol of a marriage, (Windia, 2014: 332)

When viewed from the social stratification that developed in the Balinese indigenous community, various kinds of marriage can also occur between the bride and groom pairs in the same strata or house and can also occur in different strata or house. From the point of view of Hinduism and Balinese customary law, various types of marriages should be celebrated as a symbol of marriage endorsement.

By paying attention to the description as explained above, the tendency that occurs in the field, that the reality of marital change has occurred is that the change from the way of terrorizing to be done by means of memadik or propose. This kind of community behavior can be seen as an innovation that better reflects the value of justice and is more egalitarian. In the context of Berger and Luckman's social theory 
(1966: 68), such behavior is a sign of social construction in society, namely the existence of individual desires in the community to carry out new constructs that are different from previous behavior.Based on the results of interviews that have been confirmed in a field study with Dewa Putu Mayun in Ubung Indigenous Village, Denpasar, the bride and groom in the Balinese people tend to choose marriage by marriage or marriage, because marriage by means of marriage or marriage is seen as the most ideal marriage.

In the practice of social life, research shows that most families who do marriages by means of marriage or marriage occur in a paradigm or equal social strata. But due to the increasingly complex development of social life, marriages by means of marriage or marriage are also very often done by families with different social strata, soroh or dynasty (Utomo, 2017: 89-90). Conversely, if the marriage is due to certain reasons and considerations, so that marriage by means of marriage or marriage cannot be done, then it can be reached by means of terrorism or lifting. In this way the bride and groom do the marriage by ngerorod, selari or run together (Astiti, 1981: 18). Whichever method is taken in the implementation of marriage is essentially a series of magical actions aimed at harmonizing the micro and macro-cosmos world so that the bride and groom get peace, happiness and fertility (Wignjodipoero, 1985: 122-123).

According to the great son of Ketut Sudiana as one of the traditional leaders of the City of Denpasar, in principle the marriage ceremony for indigenous people in Bali is divided into three stages, namely the first stage is called the mebyekala or mekalan-kalan ceremony or mebyekawon ceremony or called the mesen beten (below); the second stage, called the widhi wedana ceremony or mes conversions in the bale (inside the traditional house) and the third stage, the so-called tabletop ceremony or mepamit or the ceremony of carrying a pillow tip. Of these three stages, the most decisive marriage has taken place is the first stage of the ceremony, namely the mebyekala, mabyekaon or bhuta saksi.

\section{Rationality Changes in Balinese Marriage Patterns}

\section{Reactions to discriminatory customary norms}

The results of an interview with Anak Agung Ketut Arya Ardana as the leader of the Denpasar Pemogan Customary Village, stated "Bali's indigenous people in the midst of advancing information technology in the global era have experienced rapid changes. Among these changes can be seen in changes in mindset and patterns of community action based on the principles of democracy. With the application of the concept of democracy, people want an equal, equal and comfortable treatment in every interaction carried out by each individual. "

With regard to the results of the interview, it can be given an analysis that functionally, the customary institutions created in a community social system are intended to create a social order in the community. According to Comte and Spencer, in (Poloma, 1987: 25), society is seen as a social system consisting of interdependent parts of one another. Pitana (1999: 16), states that traditional villages must be able to become a vehicle for developing various positive values that exist in Balinese culture such as democratic values, and tolerance.

Analysis of social reality regarding changes in marital patterns mentioned above, has the meaning that the behavior of indigenous peoples, especially in terms of marriage has shown a change in the pattern of marriage from the pattern of marriage the way of ngerorodshifts to the way of marriage in memadik orpropose. Such a case, if examined from Dahrendorf's view is a reflection of the existence of power and authority that always places individuals in the upper and lower positions and any individual who is not subject to the existing authority will be subject to sanctions. (Dahrendorf, 1986: 255-257).

In this association, there appears to be a tension between those who are accommodated in the power structure who are trying to maintain the status quo and those who must submit to the structure. Therefore it appears that there are two types of groups involved in the conflict, namely (1), pseudo groups (quasi groups) and (2), interest groups (interest groups). The pseudo group is a group of holders of power with the same interests in maintaining that the order of customary power is applied or applied only to the nobility. Conversely, interest groups are groups who want a change in existing power, in this case the prospective bride and groom outside the nobility or three of Wangsa. When this problem is seen from Hobbes's concept of power, it is said that different interpretations based on ratios and unequal desires, 
lead to a struggle for power because of the desire to give purpose to human action, while ratio intimates the means to achieve that goal in its most tangible form called power (Cambell, 1994: 90-91).

\section{Innovative Constructive Thinking based on Religious Values}

Information obtained from Putu Winaja as Bendesa Adat Wanasari Tabanan that, "The application of marriage by means of memadik or propsed by the bride and groom in our village is a constructive and innovative act, and this marriage model is recommended in building harmony families from the beginning. The living and developing order in society has accepted this pattern of marriage well and is not against religious teachings."Acceptance of innovation by individuals in society will be influenced by socio-cultural and social systems. If the innovation is accepted by individuals in society, Rogers is called a reformer, (in Lauer, 1993: 235).

As a form of renewal which is oriented to the concept of equality or equality between individuals in the Balinese adat community, it can be seen in the following quotations from the sloka and mantram Weda.Menawa Dharmasastra III. 12: "As a first marriage it is advisable for married people to marry women who are equal, but for those who, for wanting to marry other women, it would be better if the women were in the order of their color".

This sloka means that for someone who has Madwijati means that people who have mastered science (Vedas) are encouraged to marry in a married couple of the same color (equal). Understanding the equivalent according to the provisions of Hindu law is seen in terms of a person's function and social status in society, not based on genealogy (ancestry) as is known in the dynasty system in Bali (Pudja and Rai Sudharta, 1973: 136). A similar view was also put forward by Mantra which explained that the division of colors into color chess in Hinduism was not intended to discriminate between people based on genealogical elements (ancestry), but solely based on profession and function (use and karma) (Mantra, 1974: 247 -248; Wiana and Raka Santri, 1993: 63-64).

Thus changes in marital patterns carried out in the family as Balinese society today do not deviate from the teachings of Hinduism, which highly upholds the value of humanity as God's creatures. This is confirmed in the Vedic mantram as follows: "O husband and wife, be diligent and keep working. Only those who truly succeed in this world "(Atharvaveda, VI. 122.3)"O husband and wife, you should be of noble character, full of love and intimacy between you. Do your duties and obligations properly and in accordance with applicable law.""Bring down the sons and daughters of officers, build your own home and live with joy in it", (Atharvaveda, XIV. 2.43) (in Titib, 1996: 6).

This Mantram Weda teaches all married couples to always carry out their obligations and work by following applicable laws, with the hope of achieving happiness and prosperity in their own homes. Happiness and welfare of married couples in the household will be more modest if they are blessed with sons who are officers, obedient and devoted to Hyang Widhi Waça (Titib, 1996: 6-7).

In addition, marriage according to the Hindu view is a physical bond between a man (purusa) and a woman (predana) to build a home and achieve a happy and sustainable family life goal without knowing despair. The meaning of this marriage is revealed in the holy book Menawa Dharmasastra, IX.102, as follows:"Men and women who are bound in marital ties should work hard and not be tired, so that they do not divorce and should not violate the loyalty of one another."From the Menawa Dharmasastra sloka above, a meaning can be drawn so that the husband and wife and the immediate family try as much as possible to cope with unrelenting and uninterrupted resolution of any problems that occur in domestic life that result in divorce (Gorda , 1997: 17).

In connection with the presentation of this concept, it seems clear that the perpetrators of married couples by means of memadik or propose have the purpose of carrying out renewal in society in accordance with the progress of the times as a logical consequence of the renewal movement in the field of marriage. The bride and groom are placed and given the same treatment in the marriage ceremony procession. This means that the bride and groom have received the blessing of the parents of both parties as a step to enter the household life that is harmonious and prosperous.

\section{Increased Level of Community Education}

The author's conversation with Dewa Putu Mayun, Anak Agung Ketut Sudiana as the Denpasar 
traditional leader, and I Made Nuja, the religious and traditional leader of Wanasari Village, explained that: "The level of education, insight and experience of individuals in the community is also a driving factor in changing the pattern of marriage towards marriage by means of marriage or marriage as happens to the community, both in the structure of society in rural and urban areas. Theoretically it can be said that the increasing level of education of individuals in the community in both rural and urban areas contributes to social change (Putra Agung, 1985).

Auguste Comte said that with human education will be able to open insight into his mind and direct his actions to a change in life progress, getting rid of the challenge of the ability to achieve a positive era, (Lauer, 1993: 77-78). Furthermore Bushar Muhammad (1985: 9), explained that education teaches humans to be able to think objectively, as well as to meet the demands of the times.

In addition to the level of education as above, for Berger (1994: xvi) religion is one of the most effective forms of legitimacy. Religion is a symbol that gives meaning to human life and provides the most comprehensive explanation of reality such as death, suffering, tragedy and injustice.

\section{Thinking Towards Parental-Bilateral Kinship}

The author's interview with I Nyomanganti, as Bendesa customary Kastala, Karangasem Regency, explained: "Balinese society has become a more advanced and open society in understanding the institutions in the field of marriage. With such wide open access to information and increasingly advanced education, as well as awareness of national marriage law, individuals in society have made various changes, especially in conducting marriages, no longer confined to traditional feudal customs. Even though the Balinese still adhere to a patrilineal kinship system, it does not mean that male relatives occupy a dominant position and can act arbitrarily towards women in the family ".

By advancing the principle of emancipation, equal treatment for each individual in conducting marriages, slowly marriage law also plays a role in influencing social change, especially in marriages in memadik or propose in Balinese society.

The concept of equality regulated in national marriage law is seen in the provisions governing the rights and obligations of husband and wife stating that the rights and positions of the wife are balanced with the rights and positions of the husband in domestic life and association together in the community. Each party has the right to take legal actions, the husband has the role of head of the family and the wife has the role of a housewife.

\section{Social Values and Meaning Changes in Balinese Marriage Patterns}

The reality regarding the changing behavior of marriage that is foremost in the life of the Hindu community in Bali today, theoretically can be understood as a socio-cultural change in society. That is, the Balinese indigenous people in conducting marriages are no longer confined in a custom that imperatively forces to do marriages with the old pattern of marriages in angerorod manner, but it has been very constructive in determining the choice for marriages by means of condensation or marriage. Social reality regarding marriage in marriage or marriage is one form of resistance to social institutions such as customary norms that marriage or marriage patterns only belong to the status quo of the nobility or three of Wangsa only.

The concept of thought stated above, seen from the perspective of theory in the paradigm of social definition, explains that humans are creative actors of their social reality. Human action is not entirely determined by the norms, habits and values that describe social structures and institutions in society. (Ritzer, 1992: 50).

For Berger and Luckman, exposure to the concept as explained in the paradigm of social definition is formulated into a theory known as social construction. According to Berger and Luckman (1966: 68), reality is formed socially and the sociology of knowledge is engaged in an analysis of the formation of reality by society. The reality of daily life has objective and subjective dimensions.

In more detail, the following describes the application of the concept of Berger dialectics to reflect the marriage of memadikor proposing marriageas a form of modernity in the social structure of the indigenous people of Bali. With the concept of externalization, it can be understood that humans tend to display their consciousness outwardly from the inner side into something outward. Because of that 
modern behavior that can be explained in the concept of externalization as the first concept of the dialectical triad of Berger, is a form of awareness in the form of modern consciousness that becomes outward in the practice of social life that is the act of memadik or proposing marriage.

Marriage memadik or propose as a rational act that is based on modern awareness, has a relationship with progress, individuation and equality. Progress is a time consciousness that is typical in modernity. In the dimension of individuation, subjectum also means that individuals are born into reality. Individuals free themselves from their collective entities, even contra the collectivity position by doing actions that are different from the community in their environment. (Hardiman, 2003: 96).

The second concept of Berger dialectics is known as objectivation. With the concept of objectivation, we understand that as a result of externalization it becomes an objective reality which Berger says is a sui generis reality (Hardiman, 2003: 91). In the second context of the Berger dialectical triad, modern consciousness manifests in objective reality in the form of modern institutions.

Modern social infrastructure as an objective reality in the life of the indigenous people of Bali today is in the form of a modern knowledge system and a modern press. Modern knowledge systems are the result of objectivation. The marriage of memadik or propose in the Balinese indigenous community as an individual movement in the environment of modern society, has based its behavior on the modern knowledge system, by leaving pre-modern discriminatory rules replaced with new rules that are in accordance with the culture of modern society.

This is consistent with the views of Etziony and Etziony-Halevy, which states the transition from traditional society to modern society includes eight characteristics: "(1) ademographic revolution, (2) change in the family, (3) an opening up of the stratification system, (4) a fading impact religion, (5) changes in education, (7) a growth of mass culture, and (8) an emergency of a market economy and industrialization ". (Fumie Kumigai (1995: 135).

According to Zijderveld, there are two kinds of phenomena of the attitude of consciousness that appear to the existing structure, namely adaptation and reaction (Hardiman, 2003: 102). In adaptation, individuals perform conformity, that is, modern individuals tend to accept passively and act according to the demands of the structure that impersonal control it.

Thus the pattern of marriages that occur in Bali if reflected by the theory of construction of Berger can be seen that the marriage of memadikor proposealong with other attributes is a reality created by individual human beings in society. This means that the human individual has created a social reality in the form of memadikor propose and changes in attributes related to the institution of marriage itself.

According to Suparno (1997: 28), humans construct their knowledge through interactions with objects, phenomena, experiences and their environment.

Based on the discourse in advance, it is clear that marriage in memadikor propose is the result of the social construction of individual human beings in the Balinese indigenous community as a form of resistance to the rigid patriarchal tradition.

\section{IV.CONCLUSION}

Based on the description and analysis of data as discussed earlier, a number of conclusions can be drawn as follows:

The Balinese indigenous people have made constructive changes in the institution of marriage, where the bride and groom as individuals in the community have made social changes leaving the marriage by means of ngerodot and turning to marriage by means of memadikor propose. Changes that occur in marital institutions are intended to build a family structure that is more moderate, just and fierce towards egalitarian societies by upholding equality and equality among individuals in society.

There are various thoughts or rationalities that encourage changes in marital institutions in the Balinese adat community, such as: reactions to discriminatory adat norms in the form of reactions to the establishment of discriminatory adat pariarkhi towards a more just, proportional community structure and placing women more equal and balanced with the position of women Male; innovative constructive thinking based on religion, where the Balinese indigenous people are no longer confined to feudalistic, traditional and narrow thinking but rather become an advanced society by respecting the position of men 
and women in positions of respect according to religious teachings; advancement of the education level of indigenous peoples has made a positive contribution in building understanding in accepting marriages by means of memadikor propose; and thinking towards parental-bilateral kinship becomes a strong basis for building a harmonious and just family.

Social values and meanings can be stated from the construction of this marriage, that changes in the marriage arrangements carried out by the bride and groom as individuals in the Balinese customary community are symbolic movements for renewal in the pattern of marriage by means of memadik or propose. Social changes in the institution of marriage are seen as having positive consequences in managing family responsibilities that are more in line with the values of equality, balance and justice.

\section{References}

Aditi, I.G.A. (2019). Problematic and Alternative Solutions of Different Wangsa Marriage at Balinese Community in Lombok. International Journal of Social Sciences and Humanities. Vol. 3 No 2. August 2019. P. 84-94. http://sciencescholar.us/journal/index.php/ijssh

Astiti, Tjok Istri, (1981), Perkawinan Menurut Hukum Adat dan Agama [Marriage According to Customary Law and Religion] Hindu di Bali, Denpasar:Faculty of Law, Universitas Udayana.

Bagus, M. I. (2008). Mixed Marriages in Jembrana, Bali: Mediation and Fragmentation of Citizenship and Identity in the Post-bomb (s) Bali World. The Asia Pacific Journal of Anthropology, 9 (4), 346-362. https:// doi.org/10.1080/14442210802493678

Berger, Peter, L. \& Thomas Luckmann, (1966), The Social Construction of Reality: A Treatise in the Sociology of Knowledge. Garden City, N.Y.: Doubleday \& Campany, Inc.

Berger, Peter, L., (1994), Kabar Angin Dari Langit: Makna Teologi dalam Masyarakat Modern [Rumors from the Sky: Theological Meaning in Modern Society], Jakarta: Pustaka LP3ES.

Boon, James A. (1976) The Balinese Marriage Predicament: Individual, Strategical, Cultural. American Ethnologist, Vol. 3 No.2 (May, 1976) pp.191-214. https://anthrosource.onlinelibrary.wiley.com/doi/ pdf/10.1525/ae.1976.3.2.02a00020

Budiana, I Nyoman, (2018), Perkawinan Beda Wangsa dalam Masyarakat Bali, Edisi ke 2 [Different Marriage in the House of Balinese Society, 2nd Edition], Yogyakarta: Histokultura

Bushar Muhammad, (1985), Susunan Hukum Kekeluargaan Indonesia [Indonesian Family Law Composition], Jakarta: Pradnya Paramita.

Cahyaningtyas, J. (2016). Inter-caste marriage in Bali: A gendered analysis of caste and its impact on Balinese women. Asian Journal of Women's Studies, 22(3), 193-207. https:// doi.org/10.1080/12259276.2016.1205374

Campbell Tom, (1994), TujuhTeoriSosial [Seven Social Theories], Sketsa, Penilaian, Perbandingan, Yogyakarta: Kanisius.

Collier, M. J., Ribeau, S. A., \& Hecht, M. A. (1986). Intracultural Rules and Outcomes within Three Domestic Cultures. International Journal of Intercultural Relations, 10, 439-457. Pergamon Journal Ltd. https:// doi.org/10.1016/0147-1767(86)90044-1

Dahrendorf Ralf, (1986), Konflikdan Konflik Dalam Masyarakat Industri [Conflict and Conflict in Industrial Societies], Jakarta: CV. Rajawali.

Diatmika, I.G.N.A.N and Sujana, I.N (2019) Marriage System of Nyentana and Legal Consequences for Children born in it. ICOSS 2018, September 21-22, Denpasar, Indonesia https://pdfs.semanticscholar.org/8d45/ dd30c7a6b3a4366032f7c2254b821b306852.pdf

Gorda, I Gusti Ngurah, (1997), Dasar Moral dan Motivasi Membina Perkawinan Bahagia Menurut Pandangan Hindu [Moral Basis and Motivation Fostering a Happy Marriage in a Hindu View], Denpasar: Widya Gematama.

Hardiman, F. Budi, (2003), [Beyond Positivism and Modernity], Yogyakarta: Kanisius.

Karjono, M., Bakta, I. M., Karmaya, I. N. M., Pradnyaparamita, D., \& Murtiananingsih, -. (2017). Force, support, and endorsing factors of early marriage in adolescent Sasak (Sasak Ethnic) in Central Lombok. International Research Journal of Engineering, IT \& Scientific Research, 3(2), 171-178

Korn, V.E, (1978), Het Adatrecht Van Bali (trans. Gde Wayan Pangkat), Denpasar: FHPM, Universitas Udayana.

Kumigai Fumie, (1995), Families in Japan: Beliefs and Realities (Special Issues : Families in Asia: Beliefs and Realities), Journal of Comparative Family Studies, V.26,N.1.

Lauer, H., Robert, (1993), Perspektif Tentang Perubahan Sosial [Perspectives on Social Change], Edisi Kedua, Jakarta: Rineka Cipta. 
Lestawi, I Nengah, (1999), HukumA dat [Customary law], Surabaya:Paramita.

Limarandani, N.P, Sihabudin, A, \& Ronda, M. (2019). Inter-caste Marriage and the Impact on the Intra-Cultural Communication Pattern of Balinese Hindu in Indonesia: an Ethnography Study, Asian Social Science, Vol 15 No 3 p40. http://www.ccsenet.org/journal/index.php/ass/article/view/0/38647

Lusiani, Nyoman, (2015). Pudarnya Pernikahan Ngerorod pada Masyarakat Bali Desa Tri Mulyo Kabupaten Lampung Tengah [Faded Ngerorod Marriage at Balinese Community of Tri Mulyo Village, Central Lampung Regency], Skripsi, Lampung: Pendidikan Geografi, Jurusan IPS, FKIP Universitas Lampung.

Mantra, I.B, (1994), Bagawatgita. Bali: Pemerintah Daerah Tingkah I Bali.

Panetja, Gde, (2004), Aneka CatatanTentang Hukum Adat Bali [Various Notes on Customary Law of Bali], Denpasar: Kayumas Agung.

Pitana, Gde, (1999), Transformsi Desa Adat [Transformation of Customary Villages], Jurnal Widya Satya Dharma, Vol. VI No.1, Singaraja: STIE Satya Dharma.

Poespasari, EllyneDwi, (2018), Pemahaman Seputar Hukum Waris Adat Indonesia [Understanding About Indonesian Customary Laws], Jakarta: Prenadamedia Group.

Poloma, Margaret, M., (1994), Sosiologi Kontemporer [Contemporary Sociology], Jakarta: Rajawali.

Pudja, G dan Tjokorda Rai Sudharta, (1973), Menawa Dharmasastra (Manu Dharmasastra), or WedaSmrti (Compendium Hindu Law).

Pudja, Gede, (1975), Perkawinan Menurut Hukum Hindu [Marriage according to Hindu law], Jakarta: Maya Sari.

Putra Agung, A.A. Gde, 1985, Dampak Pendidikan Terhadap Perubahan Sosial di Bali [The Impact of Education on Social Change in Bali], Yogyakarta, Penelitian Tesis, Yogyakarta: PPS Universitas Gajah Mada.

Ritzer, George, (1992), Sosiologi Ilmu Pengetahuan Berparadigma Ganda [Sociology of Multiple Paradigm Science], Jakarta: Rajawali Pers.

Robertson, Roland, (ed), (1993), Agama: Dalam Analisa dan Interprestasi Sosiologis [Religion: In Sociological Analysis and Interpretation], Jakarta: Raja Grafindo Persada.

Rogers, Everett M. and F. Floyd Shoemaker, (1981), Memasyarakatkan Ide-ide Baru [Promoting New Ideas], Surabaya: Usaha Nasional.

Sadnyini, I.A. 2016. Punishments of Brahmin Women Marriage In Bali (In The Prespective Of Hindu Values). Journal of Mimbar Hukum Vol. 28. No 3 October, 2016. Pp 544-555. https://media.neliti.com/media/ publications/138439-punishments-of-brahmin-women-marriage-in-aeb35c83.pdf

Sanderson, Stephen, K., (1993), Sosiologi Makro: Sebuah Pendekatan Terhadap Realitas Sosial [Macro Sociology: An Approach To Social Reality], Jakarta: Rajawali Pers.

Satori, Djam'andan Aan Komariah, (2017), Metodologi Penelitian Kualitatif, Cetakanke 7 [Qualitative Research Methodology, Print 7], Bandung: Alfabeta.

Shuter, R. (1990). The centrality of culture. Southern Communication Journal, 55(3), 237-249. https:// doi.org/10.1080/10417949009372792

Soerojo Wignjodipoero, (1985), Pengantar dan A sas Hukum Adat [Introduction and Principles of Customary Law], Jakarta: Gunung Agung.

Suastra, I. W. (2017). Balinese local wisdom and their implications in science education at school. International Research Journal of Management, IT and Social Sciences, 4(2), 48-57.

Suparno, Paul, 1997, Filsafat Konstruktivisme dalam Pendidikan [Philosophy of Constructivism in Education], Yogyakarta: Penerbit Kanisius.

Suyadnya, I.W. 2019 Self Identification and Reposiioning of The Tengananese in the Discourse of Adat Community in Bali. Masyarakat: Jurnal Sosiologi. Vol. 24 No 1. January 2019. Pp.27-51

Titib, I Made, (1996), Perkawinan dan Kehidupan Keluarga Menurut Kitab Suci Weda [Marriage and Family Life According to Us Suci Veda], Surabaya: Paramita.

Toyosaki, S. (2011) Critical Complete-Member Ethnography: Theorizing Dialectics of Consensus and Conflict in Intracultural Communication. Journal of International and Intercultural Communication, 4(1), 62-80, https:// doi.org/10.1080/17513057.2010.533786

Utomo, Laksanto, (2017), Hukum A dat [Customary law], Cetakan ke 2, Depok: Raja grafindo Persada.

Wiana, K., dan RakaSantri, (1993), Kasta Dalam Hindu: Kesalahpahaman Berabad-abad [Caste in Hinduism: Centuries of Misunderstanding], Cetakan pertama, Denpasar: Yayasan Dharma Naradha.

Wiana, Ketut, (1989), CaturWarna dan Permasalahannya dalamMasyarakat Hindu di Indonesia [Color Chess and Its Problems in Hindu Communities in Indonesia] (paper), Bandung: Indonesia

Widana, I. N. M. (2017). Strategy for art and cultural preservation at Balinese Hindus in Praya City, Central Lombok Regency. International Research Journal of Management, IT and Social Sciences, 4(3), 82-90. 
Windia, P. Wayan, et. al. (2008), Perkawinan Pada Gelahang di Bali [Marriage to Gelahang in Bali], $1^{\text {st }}$ ed, Denpasar: Udayana University Press.

Windia, P. Wayan, et. al. 2014, Hukum Adat Bali: Aneka Kasus dan Penyelesaiannya [Balinese Customary Law: Various Cases and Their Settlement], Denpasar: Udayana University Press. 